\title{
Reducing Barriers to Career Entry for Latinos: An Examination of Pathways into Social Work
}

\author{
Anthony De Jesús
}

\begin{abstract}
Demand for bilingual/bicultural social work practitioners presents a mutually beneficial opportunity for the social work profession and Latinos who are increasingly in positions to be employed as social workers (Acevedo, González, Santiago, \& VargasRamos, 2007; Ortíz-Hendricks, 2007). Uneven academic preparation, limited access to information about college, high tuition/opportunity costs and family obligations are among the barriers to higher education for Latinos (Arbona \& Nora, 2007; Hurtado \& Ponjuan, 2005; Ortíz et al., 2007). Using comparative methods, this article describes career pathway program models that address obstacles to successful entry into social work careers. These models also demonstrate the potential to reduce barriers to degree completion and career entry for Latinos. Salient program components include reduced tuition and tuition assistance, transportation assistance, child care, support in strengthening oral and written English skills, and access to networks of employers (Takahashi \& Melendez, 2004). Implications for social work and social work education are also discussed.
\end{abstract}

Keywords: Latinos, college completion, social work education

The expected employment growth in the social work sector suggests opportunities for Latino adults who are interested in completing degree programs in social work and are already employed in support roles in the field. The demand for bilingual/bicultural social work practitioners presents a mutually beneficial opportunity for the profession and Latino communities, whose members are both in need of social work services and, increasingly, in positions to be employed as social workers (Acevedo, González, Santiago, \& Vargas-Ramos, 2007; Ortíz-Hendricks, 2007). Anticipated growth in the social work/mental health sector underscores the demand for bilingual Latinos to enter the field as practitioners and, in turn, address the needs of their communities (Acevedo et al., 2007; Bureau of Labor Statistics 2010; Ortíz-Hendricks, 2007). Further, because migration histories, language, and culture are prominent variables in the academic success of Latinos, models advanced by social work educators who are experienced with this population provide useful examples, which may be adapted and/or replicated to increase the number of Latino social work practitioners (Gardella et al., 2005; NegroniRodriguez, Dicks, \& Morales, 2006). Based on document review and interviews with directors of career pathway models for Latino adults, this analysis describes program components of three models designed to address barriers to the completion of postsecondary credentials and to facilitate entry into the field. These barriers include costs (both monetary and opportunity costs), insufficient academic preparation, limited access

Anthony De Jesús, Ed.D., MSW, is an Assistant Professor and Director of MSW Field Education in the Department of Social Work \& Latino Community Practice at the University of Saint Joseph in West Hartford, CT. This research was supported by the Centro de Estudios Puertorriqueños (Hunter College) Pathways to Economic Opportunity Project sponsored by the Ford Foundation. The author would like to acknowledge Dr. Edwin Melendez, Director of Centro for his support of this research. 
to information about higher education, and discriminatory context (Arbona \& Nora, 2007; Hurtado \& Ponjuan, 2005; Negroni-Rodríguez et al., 2006).

According to Jenkins (2006), the concept of a career pathway reflects "a series of connected education and training programs and support services that enable individuals to secure employment within a specific industry or occupational sector, and to advance over time to successively higher levels of education and employment in that sector" (p. 6). Latinos are more likely to experience interruptions in the pursuit of higher education, especially those who begin at two-year colleges and experience difficulty transferring to four-year institutions (Hurtado \& Ponjuan, 2005; Swail, Cabrera, \& Lee, 2004; Swail, Cabrera, Lee, \& Williams, 2005). Many Latino adults with some college credits but no degree stand to benefit from career pathways designed to address barriers to college completion. Indeed, U. S. Census data presented in Tables 1 and 2 reveal that a national pool of Latino adults employed in social work and related fields would ostensibly benefit from programs designed to upgrade their skills and credentials. The broadening of pathways that tap into this pool will both facilitate the human capital development of Latino communities, and enable the social work profession to increase its capacity to serve Latino communities.

This study analyzes the program components of three career pathway initiatives targeted at supporting Latinos in enrolling and completing two- and four-year undergraduate and graduate degrees in social work. The study is guided by the following question: "Which program components assist Latinos in reducing barriers to completion of social work credentials?"

\section{Social Work Employment and Latinos}

The expected growth of social work employment in the coming years confirms the need to reduce the barriers for Latinos entering and advancing along career ladders in the field. Employment within the social work/human services sector is expected to increase by 25\% during the 2010-2020 decade. Growing elderly populations will need social services, which will lead to new positions in medical and public health social work, case management, long-term care, and gerontological social work services. In addition, positions focused on mental health and substance abuse are also projected to grow by 31\%; and medical and public health social work and social work assistant positions are expected to grow by about 22\%, a growth rate much greater than the average (Bureau of Labor Statistics, 2011). The growth of the Latino population throughout the country also presents further opportunities for Latinos trained in social work to be employed in areas where large populations of Latinos comprise the client base (Chapa \& Acosta, 2010; Hernandez \& Fitch, 2004; Ortíz et al., 2007).

A review of the occupational distribution of Latinos reporting employment in the social work sector is useful for obtaining a better understanding of the need for programs such as those described in this analysis. According to U. S. Census data reviewed below, Latinos are underrepresented, relative to the average for non-Latinos, in professional and paraprofessional social work occupations (social work and social work assistant categories). 
According to 2006-2008 data from the American Community Survey (U.S. Census Bureau, 2012), only $7.14 \%$ of all Latinos reported employment as professional social workers possessing a master's degrees and $9.24 \%$ with a bachelor's degrees (see Table 1). While a bachelor's degree is a minimum requirement for most social work positions, a number of individuals reporting employment in social work positions on the census also report educational attainment of less than a Bachelor's degree. Of all Latinos reporting employment in a professional social work role, $43.6 \%$ have yet to complete bachelor's degrees; with $13.55 \%$ possessing only high school diplomas, $16.46 \%$ having attended some college, but with no degree, and 13.65\% hold an associate's degree. Of the 811,553 adults (25 years and older) employed in social work positions in the United States, only $10 \%$, or 81,817 were Latino. This data is the best available estimate of the number of Latino social workers working at the Baccalaureate and Master's level. Individuals who report working as professional social workers who possess less than a Bachelor's degree are included in this analysis. This highlights the demand for upgrading credentials for Latinos already employed in field.

Table 1 U.S. Social Workers Educational Attainment

\begin{tabular}{lrrrrrr}
\hline & HS Diploma & Some College & Associates & Bachelors & Masters & Total \\
\hline \multirow{2}{*}{ Non-Latino } & 45,335 & 72,869 & 41,436 & 308,235 & 240,422 & 729,736 \\
& $(86.45 \%)$ & $(83.54 \%)$ & $(86.35 \%)$ & $(90.76 \%)$ & $(92.86 \%)$ & \\
Latino & 7,105 & 14,356 & 6,550 & 31,378 & 18,484 & 81,817 \\
& $(13.55 \%)$ & $(16.46 \%)$ & $(13.65 \%)$ & $(9.24 \%)$ & $(7.14 \%)$ & \\
Total & 52,440 & 87,225 & 47,986 & 339,613 & 258,906 & 811,553 \\
\hline
\end{tabular}

Source: U. S. Census Bureau, American Community Survey (2006-2008 three-year sample)

Further underscoring these disparities is the distribution of Latinos who reported employment in social work assistant roles which include, human service worker, case management aide, social work assistant, community outreach worker, community support worker, mental health aide, clinical social work aide, addictions counselor assistant, life skills counselor, family service assistant, social services aide, youth worker, psychological aide, client advocate, or gerontology aide.

As Table 2 indicates 380,940 adults were employed in social work assistant positions in the United States: with Latinos representing $12 \%(42,123)$ of this category. The over representation of Latinos in the "some college, but no degree" category is a particularly relevant data point for this analysis, one that shows that $44 \%$ of Latinos employed in social work assistant positions do not possess a bachelor degree.

The educational attainment of social work assistants closely mirrors that of the social work professional category. Fourteen percent of all Latinos employed as social and human services assistants possessed some college, but no degree, while $15.39 \%$ possessed associate's degrees and $14.31 \%$ had high school diplomas. The similarities in lack of educational attainment suggest formidable barriers to career advancement for Latinos within the field of social work, but they also suggest that a robust market exists for pathway models that address barriers to enrollment and completion of social work degrees. 
Table 2 U.S. Social and Human Service Assistants’ Educational Attainment

\begin{tabular}{lrrrrrr}
\hline & HS Diploma & Some Colleg & Associates & Bachelors & Masters & Total \\
\hline Non-Latino & 46,490 & 63,184 & 27,234 & 108,235 & 41,472 & 299,123 \\
& $(85.69 \%)$ & $(85.65 \%)$ & $(84.61 \%)$ & $(89.35 \%)$ & $(92.95 \%)$ & \\
Latino & 7,763 & 10,588 & 4,952 & 12,902 & 3,144 & 81,817 \\
& $(14.31 \%)$ & $(14.35 \%)$ & $(15.39 \%)$ & $(10.65 \%)$ & $(7.05 \%)$ & \\
Total & 54,253 & 73,772 & 32,186 & 121,177 & 44,616 & 308,940 \\
\hline
\end{tabular}

Source: U. S. Census Bureau, American Community Survey (2006-2008 three-year sample)

\section{Barriers to Attainment}

The occupational status of Latino adults in social work is not surprising when understood in the context of the literature on Latino higher educational attainment in the United States. Uneven academic preparation, limited access to information about college and graduate education, the rising cost of tuition, the opportunity costs of pursuing a degree, financial challenges, and family obligations are among the most formidable barriers to higher education experienced by Latino students. In addition, many Latinos confront discriminatory and generally adverse educational environments, which discourage their degree completion (Arbona \& Nora, 2007; Hurtado \& Ponjuan, 2005). Gardella and colleagues (2005) point out that Latino students "struggle to meet the expectations of families, employers, and academic programs that were designed for students with few external responsibilities” (p. 41). At the Master's of Social Work (MSW) level Negroni-Rodríguez and colleagues (2006) observed that Latino students were frequently adult learners with many life stressors and limited financial resources. They were more likely to extend their graduate study beyond the two-year norm and need support in finding course and field education arrangements that accommodated their employment and family responsibilities (p. 204).

The challenges described above are reflected in social work education nationally as indicated in a report by the Council on Social Work Education (CSWE) Task Force on Latino/a Social Work Education (Ortíz et al., 2007). One hundred twenty-five accredited undergraduate and graduate social work programs $(n=506)$ were surveyed in order to assess the "state" of Latinos in social work education. The study analyzed Latino student recruitment, retention, and graduation data from $25 \%$ of the nationally-accredited social work programs at the baccalaureate, master's, and doctoral levels and found Latinos to be consistently underrepresented relative to the national population (Ortíz et al., 2007). The most frequently ranked obstacles to Latino student recruitment and retention included: insufficient financial aid and the high cost of tuition; insufficient representation of Latino faculty and staff, either in the social work program or within the institution; lack of a large pool of Latino applicants; and no focused recruitment efforts toward Latino students. The most frequent reasons for not having a greater percentage of Latinos accepted into MSW programs included poor writing skills and low GPAs among Latino applicants (Ortíz et al., 2007). 
The CSWE Latino Task Force Report findings are consistent with predominant Latino attitudes toward higher education which are characterized by the belief that higher education is academically and financially inaccessible. For example, a recent Pew Hispanic Center (López, 2009) analysis "Latinos in Education: Explaining the Attainment Gap," found that although nearly $90 \%$ of Latino young adults (16-25 year olds) believe a college education is important for success in life, only $48 \%$ say that they plan to get a college degree. Of the respondents who cut their pursuit of higher education short, $74 \%$ stated their departures were due to the need to economically support their families, while half cited poor English skills (p. 6).

Higher education researchers found that Latino student attainment gaps were also related to students' experiences within adverse environments and stereotyping within institutions of higher education (Arbona \& Nora, 2007; Hurtado \& Ponjuan, 2005). They also found that a positive campus culture was a large determining factor in Latino degree attainment (López-Mulnix \& Mulnix, 2006). In a longitudinal study of Latino students' perceptions of their undergraduate experiences Hurtado and Ponjuan (2005) found that students from Spanish-language dominant households were more likely to perceive hostile campus climates than those from English language-dominant households. Hurtado and Ponjuan (2005) also found that Latino students' backgrounds were less important to retention than their sense of belonging on campus, which was facilitated by a "positive quality of interaction with diverse peers," resulting in a higher sense of belonging in college, and an "increase in confidence and skills that reflect a pluralistic orientation" (p. 248). Facilitating this sense of belonging and the development of the "capacity to manage differences and function in a diverse workplace” (Hurtado \& Ponjuan, 2005, p. 248) are among the goals of the programs described in this study.

While tuition and opportunity costs heavily influence Latinos' decisions to pursue and complete a professional degree, Hurtuado and Ponjuan (2005) argue that many Latino students also assess campus climate as a barrier-assuming that institutions of higher education are unwelcoming environments for Latino adult learners. Yosso, Smith, Ceja, and Solórzano (2009) broadly define campus racial climate as "the overall racial environment of the university that could potentially foster outstanding academic outcomes and graduation rates for all students but too often contributes to poor academic performance and high dropout rates for Students of Color" (p. 664). The perception among many Latinos that institutions of higher education are unwelcoming can only be overcome with programming that deliberately addresses these traditional barriers to Latino student engagement.

Given the underrepresentation of Latinos in social work positions nationally, and our knowledge of the challenges confronting Latinos as they endeavor to complete degrees in social work, this research seeks to describe and analyze best practices among three different pathway models designed to address these barriers (costs, academic preparation, information and adverse environments). Pathway models seek to address and reduce these barriers for Latinos who have not completed a bachelor or master degree and who may benefit from programs that lead to entrance into social work careers. 


\section{Method}

In seeking to understand more fully the characteristics of pathway models that address the needs of Latinos seeking social work credentials, this inquiry is guided by the question: "Which program components assist Latinos in reducing barriers to completion of social work degrees?” In order to answer this question, data used for this study was collected as part of the Pathways to Economic Opportunity Project for Low Wage Puerto Ricans sponsored by the Centro de Estudios Puertorriqueños (Centro) at Hunter College. A purposive sample (Maxwell, 2013; Patton, 1990) consists of three pathway programs identified from an internet search of social work/human services programs serving Latino participants and/or with programmatic missions that explicitly seek to address the barriers confronted by Latino adults in completing social work degrees. The research was supported by a larger research initiative that examined industry and community-based workforce development strategies to assist low-wage Puerto Ricans (De Jesús, 2011; Visser \& Meléndez, 2011). As a result, program selection was limited to those located in communities in the northeast United States where Puerto Ricans are the largest Latino subgroup. While these programs primarily serve Puerto Ricans, they also serve other Latinos residing in these communities and may be appropriate to adapt for use with other Latino communities. Although the findings of this study are not generalizable because of the small sample and descriptive method, this analysis provides useful insight for social work educators interested in reducing barriers for Latinos regarding which program components and organizational structures may represent promising practices. Moreover, as there are very few programs specifically targeting and/or serving Latinos, these programs illustrate the need for social work educators to develop innovative strategies for recruitment of Latino students through partnerships with community-based organizations and two-year/community college(s) in order to strengthen pathways for Latinos into the field.

The three programs analyzed differ by type of institutional host/sponsor and by the level of credentials offered. One program, the Health Careers Core Curriculum (HC4) is a union-based partnership with several campuses of the City University of New York; another, Harcum at Congreso, is a partnership between a private two-year college and a community-based non-profit organization offering an associate's degree in Human Services; and the third, the iAdelante! Bilingual Career Development Certificate at the University of Saint Joseph, offers a career development certificate leading to undergraduate degree completion and is based at a small Catholic women's university. These varying program and organizational structures provide a range of approaches targeted at addressing barriers to degree completion for Latinos. Table 3 provides basic information on each model.

This study employed a comparative case study (Miles \& Huberman, 1994; Yin, 2003) of the three pathway models and utilized multiple sources of data including interviews with program directors, published articles, annual reports, recruitment materials, brochures, and program websites. Upon obtaining the human subjects' approval, three semi-structured individual interviews were conducted with program directors, in person or via telephone, during March and April of 2010. Interviews ranged in duration from 60 to 90 minutes. Using an interview protocol adapted from Takahashi 
and Melendez (2004), the interviews focused on program characteristics, history, institutional motivation and context, recruitment and retention, support services, and program impact.

Table 3 Social Work Pathway Models

\begin{tabular}{lccc}
\hline Program & $\begin{array}{c}\text { Health Careers Core } \\
\text { Curriculum, HC4 }\end{array}$ & $\begin{array}{c}\text { iAdelante! Bilingual Career } \\
\text { Development Certificate }\end{array}$ & Harcum at Congreso \\
Institution & $\begin{array}{c}\text { 1199 SEIU Training and } \\
\text { Employment Fund }\end{array}$ & $\begin{array}{c}\text { University of Saint Joseph, } \\
\text { West Hartford, CT }\end{array}$ & $\begin{array}{c}\text { Congreso de Latinos } \\
\text { Unidos, Philadelphia, PA }\end{array}$ \\
$\begin{array}{l}\text { Program Type } \\
\text { Pre-College, Associates, } \\
\text { Bachelors, Graduate }\end{array}$ & $\begin{array}{c}\text { Undergraduate certificate, } \\
\text { Bachelor's Degree (BSW) }\end{array}$ & Associates’ Degree \\
$\begin{array}{l}\text { Number of } \\
\text { Participants }\end{array}$ & $800+$ & $10-12$ & 100 \\
\hline
\end{tabular}

Using academic databases and an Internet search, a number of peer-reviewed journal articles, documents (brochures, etc.), and websites related to each program were collected and/or accessed and utilized for data analysis. In addition, program directors provided additional written reports and program description/data. Once collected, data were analyzed using the constant comparative method, with which the researcher simultaneously codes and analyzes data in order to explore relationships, refine concepts, identify properties and integrate them into a coherent narrative (Miles \& Huberman, 1994; Taylor \& Bogdan 1984). This approach provides for a richer description of the program components that were identified to assist Latinos in overcoming barriers to entering social work pathways (Miles \& Huberman, 1994, p. 173).

\section{Results}

\section{SEIU League Training and Upgrading Fund Health Careers Core Curriculum (HC4) Program}

1199 SEIU (Service Employees International Union) is the New York City and Long Island chapter of this national union of health care workers, which has approximately 200,000 members. Approximately 14,000 union members enroll in the Union's Training and Upgrading Fund programs annually. Of these, approximately 92\% are people of color, and $12 \%$ of these are Latinos. The part-time HC4 program allows union members who are first-time or returning college students to take up to 34 credits of required college courses through the City University of New York (CUNY) and then apply those credits to healthcare-related associate's or bachelor's degree programs. Through a tuition voucher program, participants can take up to six credits per semester before incurring out-of-pocket costs.

Participants attend a required program orientation and the Training and Employment Funds' College Bound workshop, and must pass the reading and writing portions of the CUNY-ACT skills assessment. Courses are offered on CUNY campuses, at local union sites, and online. Participants are enrolled in a cohort and are supported by case managers 
and counselors who assist with course selection, provide counseling on campus and at the fund's sites, and refer students to support services as needed. Support services include tutoring and workshops that enhance study skills, time management, and computer and Internet research to assist with college-level work. Participants have seven-day access to program advisors.

Within the CUNY system, HC4 works primarily with the College of Staten Island (CSI), New York City Technical College in Brooklyn, and Lehman College in the Bronx. Each of these campuses provides academic programs in human services and/or social work, with New York City Technical College offering both an Associate's Degree in Applied Sciences in Human Services and a Bachelor's of Science in Human Services. The College of Staten Island offers a Bachelor's of Arts in Social Work (BASW) and Lehman College offers a CSWE accredited BSW and MSW program. At the undergraduate level, each of these programs focuses on generalist practices. Prospective participants in HC4 are recruited from the union membership via flyers, brochures, and advertisements in the union magazine, which is sent to members' homes. Members fill out response cards to request more information. Each year, according to the program manager, the response cards yield several hundred applicants to the program. A considerable challenge for some applicants is difficulty in passing their CUNY entrance exams, which will gain them admission into the partner CUNY campuses (College of Staten Island, Lehman College, and New York City College of Technology). These members are referred to college preparatory programs, also sponsored by the union, and may reapply to HC4 upon obtaining a passing score on the entrance exam.

\section{Harcum at Congreso, Philadelphia, PA}

In partnership with the Institute for Leadership, Education, Advancement and Development (I-LEAD) and Congreso de Latinos Unidos of Philadelphia, Harcum College, the oldest two-year degree granting institution in Pennsylvania, offers North Philadelphia residents associate's degree programs in Human Services, Law and Justice, Leadership, and Early Childhood Education. The program draws on the strengths of each partner and, in its first year, enrolled approximately 100 community residents (over $90 \%$ of the students were Latino). Congreso's 2009 annual report observed that the program was established to "address[es] many variables that weigh into creating self-sufficiency, provides entrance into higher wage employment, and increases college access by bringing college to the community" (Congreso de Latinos Unidos, 2009). According to Atlas and Mireya Leon (2010), the partners identified finances, transportation, and a discomfort with being outside of their community as the three main barriers to higher education for Latinos. As a result, key features of the program included locating the associate's degree program in the community at Congreso's facilities, which effectively addressed transportation concerns; provided subsidized tuition: and provided support services to participants. Each partner was well suited to contribute specific components of the program, as Atlas and Mireya Leon (2010) observed:

Congreso provides the long-standing history and community trust needed to attract (recruit) students, social support, facilities, and financial aid assistance; ILEAD provides leadership curricula, professional training, and academic 
assistance; and Harcum provides the accreditation, professors, curriculum, and financial aid leverage (pg. 3).

In addition, Harcum at Congreso instructors are hired based on their experience working effectively with this population and receive additional professional development from I-LEAD on how to specifically address the needs of Latino and African American students from urban communities.

While Harcum at Congreso is only in its second year, it has a documented $80 \%$ retention rate (Atlas \& Mireya Leon, 2010) and plans to expand from its current enrollment of 100 students to over 300 (Congreso de Latinos Unidos, 2009). The Human Service Curriculum is a modified version of the curriculum offered at Harcum College's main campus, which is being designed relevant to the needs of Harcum at Congreso's students. Classes are held in the heart of the Kensington community of North Philadelphia at Congreso's Education and Training center, a newly renovated facility with state-of-the-art classrooms, computer laboratories, and smart boards. Dinner is also provided for students each evening. Students are able to access a range of social services to address challenges that may interfere with their educational goals. These include case management, job readiness training, rental assistance, financial literacy programs, and tutoring. Harcum at Congreso was established in 2009 and was conceived by Congreso's former President and the Executive Director of I-LEAD, which achieved success in the development of smaller partnerships between non-profit organizations and Harcum College to serve the educational needs of employees. Harcum at Congreso began with a small cohort of Congreso employees who sought to provide themselves with opportunities to upgrade their skills and credentials at the work site. These original four employees graduated with associate degrees and have received salary increases or promotions since graduation. According to the program director, some of these program graduates had "attended larger educational institutions and felt intimidated by the competition of the other students, lost faith in themselves, and dropped out. Students here find this a more empowering model because we've brought college to them and provided them with the supports to succeed" (L. Heredia, personal communication, September 15, 2010). Although initially targeting employees, Harcum at Congreso is now using its formal partnerships and informal networks to recruit prospective students. Program staff are strengthening and developing partnerships with local high schools and other community-based organizations to recruit participants. Harcum at Congreso also emphasizes this small cohort model, as well as hiring adjunct faculty experienced in working successfully with Latino and low-income populations. In addition to these faculty resources, Harcum at Congreso students can access a range of support services provided by the agency itself, including rental assistance, financial literacy programs, case management, and job readiness training. As the program director observed, the program was specifically designed to provide students with a range of support services and to address "any and all social barriers that our students would face that would hinder their academic success” (L. Heredia, personal communication, September 15, 2010).

While not a program accredited by the CSWE, the Human Service program at Harcum at Congreso represents an important model for social work educators to consider because of its innovative partnership model and comprehensive support services. 


\section{University of Saint Joseph, West Hartford, CT: ¡Adelante! Bilingual Career Development Certificate}

The iAdelante! Bilingual Career Development Certificate program at the University of Saint Joseph (USJ), in West Hartford, CT, was designed to allow bilingual working adults with some college credits to obtain an undergraduate career development certificate with the goal of completing their BSW degree. Participants are admitted into the University's undergraduate Weekend Program for Adult Learners and complete four specialized courses for the certificate: Prior Learning and Adult Education, Business and Professional Communication, Latino/a Storytelling, and Community Interpreting and Cultures. ¡Adelante! (English translation is forward.) is housed within the college's Department of Social Work and Latino Community Practice and serves 12 students through: 1) affordable tuition for part-time returning students; 2) flexible schedules that accommodate working adults; 3) bilingual faculty advisors and faculty mentors; 4) individualized tutoring and academic support; 5) classes conducted in Spanish and English; 6) culturally relevant curricula; and 7) inclusion of families and communities in the college experience. In addition, the program offers students a one-credit course, the Latino Community Writing Circle, which provides ongoing support to students in developing writing skills with an emphasis on social work writing (case notes, biopsychosocial assessments, etc.).

iAdelante!, in its third year, serves 12 Latino students, the majority of whom are from the Greater Hartford area. According to the program director, of the 11 students in the first cohort, $100 \%$ successfully completed the Certificate and matriculated into bachelor's degree programs. After receiving a \$50,000 grant from ¡Excelencia! in Education and recruiting two Latina professors, ¡Adelante! has developed a promising and innovative infrastructure to strengthen the human capital of Latino adults in social work. Students earn the certificate upon completion of the four-course sequence. Each credit satisfies general education distribution requirements and is transferable to a fouryear bachelor's degree program. In addition to continuing within USJ's Weekend Program for Adult Learners, iAdelante! has also negotiated matriculation agreements with other local community colleges and institutions like Tunxis Community College and Capitol Community College.

¡Adelante! utilized focus groups with prospective students and employers to develop its recruitment strategies. These included formal and informal approaches aimed both at recruiting "one student at a time," and strategically strengthening relationships with larger institutional employers with access to resources for tuition reimbursement. Emphasizing the importance of relationship building and trust in recruitment, the ¡Adelante! program director observed:

We have been going to state workforce development programs that, at least at one time, had some money, and might in the future. In Connecticut, a priority area for incumbent worker funding is health, so this is a perfect opportunity for us. So, for example, a year ago would have been the case, that Hartford Hospital had a group of employees interested in ¡Adelante! They might have received 
$\$ 25,000$ from the state that they could use toward tuition support for those employees (L. G. Gardella, personal communication 4/22/10).

Recognizing the prohibitive cost of private higher education, $¡$ Adelante! has sought to strengthen relationships with institutional partners who can provide resources for upgrading their workers' skills and credentials. These included large private agencies, state agencies, and health care institutions with which USJ has long-term ties. ¡Adelante! continues to develop and strengthen relationships with large employers in health and human services and work with agencies who can apply for incumbent worker funding.

The University of Saint Joseph offers students the most support in this area by making career development an explicit part of the program's name. The program director described how the program is specifically designed to advance student workers on a career trajectory in social work:

It's the ¡Adelante! Certificate in Career Development for Bilingual Professionals, so it's very explicitly about career development, and that is how you attract adults to college. Not by saying, "you'll love it," and "it'll improve the opportunities for your children." All that's true, but what really attracts people tends to be career opportunities and advancement, and we mean it. So this program is very specifically looking at bilingual career development. Students begin by making an educational and professional plan, and then we help them to realize that plan. They improve their English and Spanish communication skills, which will help them advance in college, as well as in the workplace (L. G. Gardella, personal communication 4/22/10).

¡Adelante! provides Latino adult workers with a pathway to enter or re-enter college through admission in USJ's Weekend Program for Adult Learners where they may elect to major in social work or other professional fields. The unique nature of the social work and Latino Community Practice department, which also houses a post baccalaureate certificate in Latino Community Practice (LCP), provides an extended pathway through the bachelor's degree for iAdelante! students who are interested in social work careers.

\section{Discussion}

The pathway programs analyzed identify several key areas of need for Latino adults including tuition support, academic support, and support services to students. Affordable tuition and prepaid tuition vouchers; culturally relevant curricula, flexible schedules, credit transfers, supervised internships; and counseling, tutoring, and mentoring from bilingual faculty are among the services identified by Negroni-Rodriguez and colleagues (2006) as critical for Latino student success in social work education.

Key program components offered by these models include academic advising, mentoring, and tutoring geared toward addressing academic and other needs of Latino students. For example, HC4 provides its participants with academic counselors at each of the campus sites to whom they have access seven days a week. These participants also have access to tutors who assist them in preparing for the CUNY Proficiency Exam (CPE) that they must pass in order to transition to a four-year program of study. 
Participants in USJ's ;Adelante! program are each assigned a Latina faculty mentor who provides additional academic support and an opportunity to develop a close relationship with a faculty member. In addition, three of the four courses students take in the program are taught by bilingual faculty. The small size of the cohort also fosters mutual support and community building among students facilitated by faculty. Harcum at Congreso students may receive a range of support services provided by Congreso's social service department including rental assistance, financial literacy programs, case management, and job readiness training. As the programs within the private institutions are smaller, they may have additional capacity to personalize advising and mentoring, as well as incorporate families in supporting and celebrating student accomplishments. This is most evident within Adelante's year-end recognition where family members are invited to a special graduation ceremony and are acknowledged for the support they have provided their relative.

The pathway programs described herein represent novel and innovative institutional responses to supporting the career development of Latino adults. Furthermore, the programs provide the field with the human capital necessary to meet the demand for bilingual, bicultural social workers. While more comprehensive evaluation is needed to ascertain the full impact of these programs, many opportunities and challenges are evident from the data available. As a descriptive case study of three programs, these findings are not generalizable. In addition, these programs are geographically located in the Northeast United States in Latino communities with large concentrations of Puerto Ricans and Dominicans. As such, the programs may not address needs specific to other Latino subgroups such as Cubans and Central, and South Americans. Despite these limitations, the programs described represent innovative approaches to addressing barriers to career entry for Latino adults, which may be adapted for use with other populations and have considerable implications for social work education. In addition, these programs may provide a blueprint for a redesign of social work education that reduces barriers for Latinos to access undergraduate and graduate social work programs, persist, and complete the MSW.

Alternatively, social work educators who are eager to address the needs of Latinos may generate unrealistic expectations of what can be accomplished by addressing the most obvious barriers to completion of degrees. In their enthusiasm to remove barriers to degree completion, administrators must be aware that not all Latino workers eligible for programs will succeed due to insufficient academic preparation and competing demands. Admission criteria should carefully evaluate the student's ability to persist to graduation with available resources in order not to set them up for failure.

An important issue for further analysis is the lack of clarity regarding how participants may upgrade and transfer credits and credentials from one institution to another. While matriculation agreements exist within the CUNY system and iAdelante!, at the University of Saint Joseph, these agreements have yet to be solidified at Harcum at Congreso. In addition, there is a need for resolving issues of transferability of credits from associate's degree programs accredited by the Council on Standards for Human Service Education and Bachelor's Degree programs in Social Work accredited by the CSWE (Topuzova, 2006). Resolution of these issues would assist in establishing a more 
streamlined educational pathway for all, which would clearly benefit Latinos enrolled in these programs. Many challenges remain in creating seamless pathways into social work for Latinos, however demand for bilingual and culturally competent practitioners calls for innovation.

\section{Conclusion}

Nationally, Latino adults suffer from inadequate opportunities, as a result of lower educational attainment, and they confront multiple barriers in their pursuit of skills and credentials (Hurtado \& Ponjuan, 2005; Takahashi \& Meléndez, 2004). At the same time, census data described here reveals a pool of Latinos who are already employed in the social work sector, but who have not completed undergraduate and graduate degrees in social work. The programs examined in this analysis demonstrate that career pathways for Latinos into social work demonstrate great potential to reduce barriers to degree completion and career entry. Social work credentials provide Latinos a dual opportunity to enter a profession where they may earn a livable, middle-class wage with access to benefits that will enable them to strengthen their communities as they provide essential social and mental health services to Latino populations. This dual opportunity is also highly attractive to the reciprocal desires of many Latino adults to "give back" to one's community. Social work pathways for Latinos benefit the profession, the individual practitioner, and the communities to which they will eventually provide services (Chapa \& Acosta, 2010; Hernández \& Fitch, 2004; Negroni-Rodriguez et al., 2006; Ortíz et al., 2007; Ortíz-Hendricks, 2007). Social work educators are well positioned to develop partnerships that integrate these components as a strategy to increase the number of Latinos obtaining professional social work credentials.

\section{References}

Acevedo, G., Gonzalez, M. J., Santiago, V., \& Vargas-Ramos, C. (Fall 2007). The state of Latino health and mental health. New York, NY: Hunter College, Center for Puerto Rican Studies, Policy Report, 1(4), 1-23. Retrieved from http://centropr.hunter.cuny.edu/sites/default/files/working_papers/LatinoHealth$\underline{\text { R.pdf }}$

Arbona, C., \& Nora A. (2007). The influence of academic and environmental factors on Hispanic college degree attainment. The Review of Higher Education, 30(3), 247269.

Atlas, J., \& Mireya Leon, I. (2010, Winter). Congreso: Building nonprofit partnerships and determining their financial costs. Philadelphia Social Innovations Journal, Issue 2. Retrieved from www.philasocialinnovations.org

Bureau of Labor Statistics, U.S. Department of Labor, Occupational Outlook Handbook, 2012-13 Edition, Social and Human Service Assistants, on the Internet at http://www.bls.gov/ooh/community-and-social-service/social-and-human-serviceassistants.htm 
Chapa, T., \& Acosta, H. (2010, February). Movilizandonos por Nuestro Futuro: Strategic Development of a Mental Health Workforce for Latinos. Washington, DC: Office of Minority Health and the National Resource Center for Hispanic Mental Health, United States Department of Health and Human Services.

Congreso de Latinos Unidos. (2009). Annual Report. Retrieved from http://www.congreso.net/annualreportfy09.htm

De Jesús, A. (2011). Abriendo Caminos: An analysis of three social work pathways for low wage Puerto Ricans. Centro: The Journal of Puerto Rican Studies, 23(2), 136155.

Gardella, L. G., Candales, B. A., \& Ricardo-Rivera, J., (2005). Doors are not locked, just closed: Latino perspectives on college. In M. A. Wolf (Ed.), Adulthood: new terrain (pp. 39-52). San Francisco: Josey-Bass.

Hernández, S. H., \& Fitch, D. (2004). Ideological dislocation: Implications for mentoring Latino social work faculty (Unpublished manuscript).

Hurtado, S., \& Ponjuan, L. (2005). Latino educational outcomes and the campus climate. Journal of Hispanic Higher Education, 4, 235.

Jenkins, D. (2006). Career Pathways: Aligning Public Resources to Support Individual and Regional Economic Advancement in the Knowledge Economy. Barrington, RI: Workforce Strategy Center. Retrieved from http://www.workforcestrategy.org/images/pdfs/publications/WSC_pathways8.17.06. pdf

López, M. H. (2009). Latinos and Education: Explaining the Attainment Gap. Washington, DC: Pew Research Center, Pew Hispanic Center. Retrieved from http://www.pewhispanic.org/files/reports/115.pdf

López-Mulnix, E. E., \& Mulnix, M. W. (2006). Models of excellence in multicultural colleges and universities. Journal of Hispanic Higher Education, 5(1), 4-21.

Maxwell, J. A. (2013). Qualitative research design: An interactive approach. Thousand Oaks, CA: Sage.

Miles, M. B., \& Huberman, A. M. (1994). Qualitative data analysis: An expanded sourcebook $\left(2^{\text {nd }}\right.$ ed.). Thousand Oaks, CA: Sage.

Negroni-Rodríguez, L. K., Dicks, B., \& Morales, J. (2006). Cultural considerations in advising Latino/a students. Journal on Teaching in Social Work, 6(1/2), 201-221.

Ortíz, L., Bern-Klug, M., Leighninger, L., Negroni-Rodriguez, L., Rodriguez, N., \& Sheridan, P. (2007). Final Report to the Council on Social Work Education Board of Directors. Alexandria, VA: Council on Social Work Education, Task Force on Latino/as in Social Work Education. Retrieved from http://www.cswe.org/File.aspx?id=55345

Ortíz-Hendricks, C. (2007). Supply and Demand for Latina/o Social Workers: Latino Social Work Task Force Spurs Collaboration and Action. New York: NASW New 
York City Chapter. Retrieved from:

http://www.naswnycarchives.net/CSPP/LatinoCommunities/SupplyandDemand.html

Patton, M. Q. (1990). Qualitative evaluation and research methods (2 ${ }^{\text {nd }}$ ed.). Newbury Park, CA: Sage.

Swail, W., Cabrera, A., \& Lee, C. (2004). Latino youth and the pathway to college. Washington, DC: Educational Policy Institute.

Swail, W., Cabrera, A., Lee, C., \& Williams, A. (2005). Latino students and the educational pipeline. Part III: Pathways to the bachelor's degree for Latino students. Washington, DC: Educational Policy Institute and Lumina Foundation for Education.

Takahashi, B., \& Melendez, E. (2004). Union-sponsored workforce development initiatives. In E. Melendez (Ed.), Communities and workforce development (pp. 131162). Kalamazoo, MI: W. E. Upjohn Institute for Employment Research.

Taylor, S. J., \& Bogdan, R. (1984). Introduction to qualitative research methods: The search for meanings. New York: John Wiley \& Sons.

Topuzova, L. (2006). Community Colleges and the Preparation of the U.S. Human Services Workforce. Alexandria, VA: Council on Social Work Education. Retrieved from http://www.cswe.org/File.aspx?id=16354

U. S. Census Bureau. (2012). American Community Survey; 3yr 2006-08 sample. Retrieved from http://factfinder2.census.gov/faces/nav/jsf/pages/index.xhtml

Vidal de Haymes, M., \& Kiltey, K. (2007). Latino population growth, characteristics and settlement trends: Implications for social work education in a dynamic political climate. Social Work Education, 43(1), 101-116.

Visser, A., \& Meléndez, E. (2011). Puerto Ricans in the U.S. low-wage labor market: Introduction to the issues, trends and policies. Centro: The Journal of Puerto Rican Studies, 23(2), 4-19.

Whitaker, T. (2008). Who wants to be a social worker? Career influences and timing. NASW Membership Workforce Study. Washington, DC: National Association of Social Workers.

Yin, R. K. (2003). Applications of case study research ( $2^{\text {nd }}$ ed.). Thousand Oaks, CA: Sage.

Yosso, T., Smith, W. A., Ceja, M., \& Solórzano, D. G. (2009). Critical race theory, racial microaggressions, and campus racial climate for Latina/o undergraduates. Harvard Educational Review, 79(4), 659-691.

\section{Author note:}

Address correspondence to: Anthony De Jesús, Ed. D., MSW, Assistant Professor and Director, MSW Field Education, Department of Social Work \& Latino Community Practice, University of Saint Joseph, 1678 Asylum Avenue, Mercy 246, West Hartford, CT 06117. Phone: 860-231-5563 Email: adejesus@usj.edu 